\title{
Evaluation of Urea Ammonium Nitrate Application on the Performance of Wheat
}

\author{
Prem K. Sundaram ${ }^{1}$, Indra Mani², Satish D. Lande ${ }^{2}$ and Roaf Ahmad Parray ${ }^{2}$ \\ ${ }^{1}$ ICAR-Research Complex for Eastern Region, Patna, Bihar, India 800014 \\ ${ }^{2}$ ICAR-Indian Agricultural Research Institute, New Delhi, India 110012 \\ *Corresponding author
}

\begin{tabular}{|l|}
\hline Ke y w o r d s \\
$\begin{array}{l}\text { Urea, Ammonium } \\
\text { nitrate, Growth } \\
\text { parameters }\end{array}$ \\
\hline Article Info \\
\hline $\begin{array}{l}\text { Accepted: } \\
\text { 14 December } 2018 \\
\text { Available Online: } \\
\text { 10 January } 2019\end{array}$ \\
\hline
\end{tabular}

An experiment was carried out to know the influence of application of different basal dose $(50$ and $80 \% \mathrm{~N})$ of liquid fertilizer Urea Ammonium Nitrate at different application depth ( 7 and $9 \mathrm{~cm}$ ) on wheat growth parameters. The basal dose was provided with UAN and thereafter by foliar spray of UAN. Different crop growth parameters like germination count, plant height, number of tillers per $\mathrm{m}$ row length, grain yield and biological yield of wheat crop were studied. Plot with urea application was taken as control plot. The minimum germination count was observed when UAN in higher amount $(80 \% \mathrm{~N}$ as basal dose) was placed at depth of $7 \mathrm{~cm}$ from surface. This may be because of toxicity of higher concentration of UAN placed in close proximity $(3 \mathrm{~cm}$ distant) of seed. Number of tillers per $\mathrm{m}$ in the treatment $80 \%$ basal does of UAN (120 kg N/ha) at $9 \mathrm{~cm}$ depth were either at par or significantly higher compared to number of tillers observed in recommended dose of fertilizer $(50 \%$ basal dose of Nitrogen through Urea @ $150 \mathrm{~kg} \mathrm{~N} / \mathrm{ha})$. Among all the treatments, placement of $80 \%$ basal does of UAN at $9 \mathrm{~cm}$ from soil surface give the highest number of tillers per metre row length. The highest and lowest biological yield of $1680 \mathrm{~g} / \mathrm{m}^{2}$ and $1320 \mathrm{~g} / \mathrm{m}^{2}$ was observed in treatments observed when $80 \%$ basal dose of $\mathrm{N}$ was applied at $9 \mathrm{~cm}$ and $7 \mathrm{~cm}$, respectively. The higher biological yield observed in $80 \% \mathrm{~N}$ as basal dose compared to $50 \% \mathrm{~N}$ may be due to effect of Nitrogen on vegetative growth of wheat.

\section{Introduction}

Major fertilizer sources consumed in India are Urea, NPK complex, Di-Ammonium Phosphate (DAP), Single superphosphate and Muriate of Potash (MOP) (Anonymous, 2016). Commercially, urea is mainly produced in a solid form, either as prills, granules or super granules. One way to use granular urea is to go for its use in aqueous form. Studies suggested that application of aqueous urea at root zone depth enhanced growth performance parameters in addition to better germination (Sundaram, 2017). Due to the limitations of prilled urea, liquid fertilizers are popular in foreign countries viz. USA, European Union, Australia and many more. The most widely used nitrogen based liquid fertilizer is in these countries are Urea Ammonium Nitrate (UAN) which is an aqueous solution of urea [CO $\left.\left(\mathrm{NH}_{2}\right)_{2}\right]$ and ammonium nitrate $\left[\mathrm{NH}_{4} \mathrm{NO}_{3}\right]$. It contains 
nitrogen $(\mathrm{N})$ between 28 to 32 per cent. The $\mathrm{NO}_{3}^{-}$portion (25\% of the total $\mathrm{N}$ ) is immediately available for plant uptake. The $\mathrm{NH}_{4}{ }^{+}$fraction $(25 \%$ of the total $\mathrm{N}$ ) can also be assimilated directly by most plants, but is rapidly oxidized by soil bacteria to form $\mathrm{NO}_{3}$ (nitrate). Soil enzymes hydrolyse the remaining urea portion (50\% of the total $\mathrm{N}$ ) to form $\mathrm{NH}_{4}{ }^{+}$, which subsequently transforms to $\mathrm{NO}_{3}{ }^{-}$in moist soil conditions. Solutions of UAN are extremely versatile as a source of plant nutrition. Its chemical properties make UAN compatible with many other nutrients and agricultural chemicals and can be mixed with solutions containing phosphorus, potassium and other essential plant nutrients.

UAN can be injected into the soil beneath the surface, sprayed onto plant leaves as a source of foliar nutrition and can be added to irrigation water for fertigation. UAN was the most efficient $\mathrm{N}$ source as compared with Calcium Ammonium Nitrate (CAN) and Anhydrous Ammonium (AA), as it provided the greatest crop response and greatest inorganic soil availability (Gagnon and Ziadi 2010).

Fluid fertilizers are blended to precisely meet the specific needs of a soil or crop (IPNI, 2017).National Fertilizer Limited, a public sector company in India had developed a liquid fertilizer 'Ankur' which was found to be as good as urea and Calcium Ammonium Nitrate (CAN) for wheat (Anonymous 2012).However, it could not be popularized due to lack of storage facility, transport and lack of applicator. It is necessary to place liquid fertilizer at such a depth which will give better seed germination without damaging the seeds as well as easy availability of nutrients to the primary and secondary roots. To place the liquid fertilizer at different depth a tractor drawn applicator was developed.

\section{Materials and Methods}

Urea ammonium nitrate fertilizer was applied at different soil depth of 7 and $9 \mathrm{~cm}$ using UAN applicator (Fig. 1).

\section{Field experiment for measurement of crop performance parameters}

Wheat (HD-2967) was sown in the experimental field at Indian Agricultural Research Institute, New Delhi on $25^{\text {th }}$ November 2017. Wheat sowing was carried out by delivering the seed to a depth of $4 \mathrm{~cm}$ from soil surface and the liquid fertilizer (UAN) in two different basal doses $(50 \% \mathrm{~N}$ and $80 \% \mathrm{~N}$ ). The response of wheat to UAN application in different doses at different depths was analyzed by evaluating the crop growth parameters like germination count, plant height, number of tillers and number of spikes per metre row, grain yield and biological yield. The size of experimental plot was $40 \mathrm{~m}$ x $40 \mathrm{~m}$. The soil of the IARI farm was classified as alluvial soil and was of sandy loam texture. The Farm was situated at latitude $28.40 \mathrm{~N}$, longitude $77.10 \mathrm{E}$ and at an altitude of 227 meter above mean sea level.

The average soil moisture content during the sowing was $11.5 \pm 0.67$ per cent. The experiments were laid down to determine the influence of UAN application depth as well as basal dose on crop growth. Five treatment combinations T1, T2, T3, T4 and T5 (Table 1) with three replications were applied in Randomized block design (RBD) for conducting field study. Two irrigations were applied during the crop experimentation period.

Mean monthly meteorological data recorded at the meteorological observatory at IARI, New Delhi for 2017-18 for Rabi season is presented in Figure 2 and Table 2. 


\section{Measurement of crop growth parameters}

To evaluate performance of Urea Ammonium Nitrate, different crop growth parameters like germination count, plant height, number of tillers per $m$ row length, grain yield and biological yield of wheat crop were studied. These parameters were evaluated for two different basal doses of Nitrogen through UAN (50\% and $80 \%)$ applied at two different depths $(7 \mathrm{~cm}$ and $9 \mathrm{~cm})$ from surface. As a control treatment, the parameters were also studied for basal dose of Nitrogen through urea applications.

\section{Germination count}

The germination count was recorded 11 and 18 days after sowing. For this, in every replication of the treatments at three places, crop row length of 1 meter was randomly selected and number of germinated seeds was counted. Arithmetic mean of three counts gave average germination of that plot. These test locations were earmarked for further reference.

\section{Plant height}

Plant height is an important growth parameter. Ten wheat plants were randomly selected from each marked space and height of plants was measured from base of the plant to the top of the main shoot by meter scale. The plant heights were recorded at 45, 72 and 120 days after sowing.

\section{Tillering count}

The tillering count was done at 45 DAS, 72 DAS and 120 days after sowing. Three replications of $1 \mathrm{~m}$ row length were taken to count number of tillers. These were averaged to estimate total number of tillers per meter row length at respective stage.

\section{Grain and biological yield}

A crop cutting experiment was conducted to evaluate the grain and straw yield from different plots. The crop within $1 \times 1 \mathrm{~m}$ size area marked by M.S. flat made square frame was harvested manually. After sun drying these were weighed to record biological yield. The crop was threshed by plot thresher and was weighed. The grains were separated from threshed crop using a blower. The weight of clean grain collected was measured by a balance.

\section{Results and Discussion}

\section{Effect of UAN basal dose and application depth on germination count}

The data on germination count was observed at 11 and 18 days after sowing, Table 3. The average number of plants per $m$ row length at 11 DAS was 16, 11, 16, 14 and 15 in the treatment $\mathrm{T} 1, \mathrm{~T} 2, \mathrm{~T} 3, \mathrm{~T} 4$ and $\mathrm{T} 5$, respectively. With the advancement of time more number of seeds germinated and the number of seeds per $m$ row length observed at 18 DAS were $75,62,82,88$ and 81 in treatments T1, T2, T3, T4 and T5, respectively. Placement of UAN in higher amount $(80 \% \mathrm{~N}$ as basal dose) at shallower depth $(7 \mathrm{~cm})$ gave less germination count as compared to other treatments. Initially, seed germination count in different treatments was at par with each other, however at 18 DAS significant difference in germination count was observed between different treatments at $5 \%$ level of significance.

The minimum germination count was observed when UAN in higher amount $(80 \%$ $\mathrm{N}$ as basal dose) was placed at depth of $7 \mathrm{~cm}$ from surface. This was probably because of toxicity of higher concentration of UAN placed in close proximity $(3 \mathrm{~cm}$ distant $)$ of seed. Toxicity effect of UAN has been 
reported by many researchers (Cooke, 1962; Radford, 1989; Pan et al., 2016).

Effect of UAN basal dose and its application depth on plant height

Wheat plant height was measured at 45,72 and 120 DAS from the treatment plots, Table 4. As a control treatment, Urea was also applied in one of the treatment plots with recommended basal dose for wheat. The plant height $(\mathrm{cm})$ observed at 45 DAS were 36,34 , 42, 41 and 35 for treatments T1, T2, T3, T4 and $\mathrm{T} 5$, respectively. The corresponding values at 120 DAS were $86,87,89,89$ and 86 , respectively. Plant height at 45 and 72 DAS was affected by both basal dose as well as depth of placement and the effect was significant effect at $5 \%$ level of significance. However, plant height observed at 120 DAS under different treatments was at par with each other. The maximum plant height at 120 DAS in both the UAN basal doses was obtained when UAN was placed at a depth of $9 \mathrm{~cm}$ from soil surface.

\section{Effect of UAN basal dose and its application depth on no. of tillers}

Data on number of tiller per meter row length, an indicative of potential crop yield, was observed at 45,72 and 120 DAS of wheat crop, Table 5. Numbers of tillers per metre row length at 45 DAS were in same order observed as 157, 140,157, 159 and 152 in treatments T1, T2, T3, T4 and T5. Except T2 $\left(\mathrm{B}_{80 \%} \mathrm{D}_{7}\right)$, in all UAN based treatments, the number of tillers per $m$ row length was higher compared to that in urea based treatment. In case of $\mathrm{T} 2$, the number of tillers per metre row length was significantly less than that in other treatments at a significance level of 5 per cent. The number of tillers per $\mathrm{m}$ length observed close to maturity stage i.e. 120 DAS were 165, 144, 173, 167 and 164 in treatments T1, T2, T3, T4 and T5, respectively. Number of tillers per $\mathrm{m}$ in the treatment $80 \%$ basal does of UAN(120 kg N/ha) at $9 \mathrm{~cm}$ depth were either at par or significantly higher compared to number of tillers observed in recommended dose of fertilizer $(50 \%$ basal dose of Nitrogen through Urea @ $150 \mathrm{~kg}$ $\mathrm{N} / \mathrm{ha}$ ). Among all the treatments, placement of $80 \%$ basal does of UAN at $9 \mathrm{~cm}$ from soil surface give the highest number of tillers per metre row length. The maximum and minimum number of tillers per metre row length observed at 45 DAS, 72 DAS and 120 days after sowing of wheat crop were 159 and 140, 191 and 161, and 173 and 144, respectively. It was observed that in all UAN based treatments, the number of tillers per $m$ was higher compared to Urea based treatment. The only exception to this observation was the treatment in which $80 \%$ Nitrogen as basal dose was applied at a depth of $7 \mathrm{~cm}$. In this treatment, the number of tillers per $m$ row length was comparatively less probably because of low germination count. Among all the treatments placement of UAN at $9 \mathrm{~cm}$ from soil surface gave the highest number of tillers per metre row length. Wu et al., (2017) reported that nitrogen deep placement could maintain high fertilizer $\mathrm{N}$ supply in deep soil layers $(5-20 \mathrm{~cm})$ and induce plants to absorb more $\mathrm{N}$ and thus producing more number of tillers.

\section{Effect of UAN basal dose and application depth on biological and grain yield}

The estimated relative yield of the crop under different treatments was evaluated by measuring the grain yield per unit area $\left(\mathrm{g} / \mathrm{m}^{2}\right)$ of the crop area, Table 6 . The highest grain yield of $736 \mathrm{~g} / \mathrm{m}^{2}$ was observed in the treatment in which $80 \%$ basal dose of $\mathrm{N}$ in the form of UAN was applied at a depth of $9 \mathrm{~cm}$ from soil surface (T4). The grain yield in treatment T1, T2, T3 and T5 was observed as $650,522,555$ and 687 gram per square metre, respectively. The grain yield in $\mathrm{T} 1$ and $\mathrm{T} 5$ 
was at par with each other but significantly higher than $\mathrm{T} 2$ and $\mathrm{T} 3$ at $5 \%$ level of significance (Appendix-M5). The yield obtained in $80 \%$ basal dose of $\mathrm{N}$ through UAN (120 kg N/ha) placed at $9 \mathrm{~cm}$ resulted in significantly higher yield to the tune of $7 \%$ than that with urea application $(150 \mathrm{kgN} / \mathrm{ha})$.

Along with grain yield, biological yield of the wheat crop was also determined. The biological yields observed in treatment $\mathrm{T} 1, \mathrm{~T} 4$ and $\mathrm{T} 5$ were significantly higher as compared than $\mathrm{T} 2$ and $\mathrm{T} 3$ at $5 \%$ level of significance. The highest and lowest biological yields of $1680 \mathrm{~g} / \mathrm{m}^{2}$ and $1320 \mathrm{~g} / \mathrm{m}^{2}$ were respectively observed in treatments T4 and T2. Similar to grain yield, the treatment $80 \%$ basal dose of $\mathrm{N}$ through UAN at $9 \mathrm{~cm}$ depth resulted in higher biological yield $(3.5 \%)$ compared to Urea application.

Table.1 Details of different treatments for field evaluation of Urea Ammonium Nitrate

\begin{tabular}{|c|c|c|c|}
\hline Treatments & Details & $\begin{array}{c}\text { Basal } \\
\text { applicatio } \\
\mathrm{n} \mathrm{kgN/ha}\end{array}$ & $\begin{array}{c}\text { UAN applied } \\
\text { I/ha }\end{array}$ \\
\hline $\begin{array}{l}\text { T1 } \\
\left(\mathbf{B}_{50 \%} \mathbf{D}_{7}\right)\end{array}$ & UAN@120 kg N/ha-50\%N-B- $7 \mathrm{~cm}+50 \%$ N-FS & 60 & 170 \\
\hline $\begin{array}{l}\mathbf{T 2} \\
\left(\mathbf{B}_{80 \%} \mathbf{D}_{7}\right)\end{array}$ & UAN@120 kg N/ha-80\%-B- 7 cm+20\%N-FS & 96 & 272 \\
\hline $\begin{array}{l}\mathbf{T 3} \\
\left(\mathbf{B}_{50 \%} \mathbf{D}_{\mathbf{9}}\right)\end{array}$ & UAN@120 kg N/ha-50\%N-B- $9 \mathrm{~cm}+50 \%$ N-FS & 60 & 170 \\
\hline $\begin{array}{l}\text { T4 } \\
\left(\mathbf{B}_{80 \%} \mathbf{D}_{9}\right)\end{array}$ & UAN@120 kg N/ha-80\%N-B- $9 \mathrm{~cm}+20 \%$ N-FS & 96 & 272 \\
\hline $\begin{array}{l}\text { T5 } \\
\text { (Control) }\end{array}$ & $\begin{array}{l}\text { Urea @ } 150 \text { kg N/ha- } 50 \% \text { N-B + 25\% N-TD +25\% } \\
\text { N-TD }\end{array}$ & 60 & - \\
\hline
\end{tabular}

B- Basal, TD-Top dress, FS-Foliar Spray,

Table.2 Mean monthly meteorological data for the year 2017-18 at IARI farm

\begin{tabular}{|l|c|c|c|c|c|c|c|}
\hline \multirow{2}{*}{ Months } & \multicolumn{3}{|c|}{ Temperature, ${ }^{\circ} \mathbf{C}$} & \multicolumn{3}{c|}{ Relative humidity, \% } & Rainfall, \\
\cline { 2 - 8 } & $\mathrm{T}_{\max }$ & $\mathrm{T}_{\min }$ & $\mathrm{T}_{\text {mean }}$ & $\mathrm{RH}(\mathrm{M})$ & $\mathrm{RH}(\mathrm{E})$ & $\mathrm{RH}(\mathrm{mean})$ & $\mathbf{m m}$ \\
\hline October & 34.0 & 17.2 & 25.6 & 92.2 & 43 & 68 & 0.0 \\
\hline $\begin{array}{l}\text { Novembe } \\
\text { r }\end{array}$ & 26.8 & 10.6 & 18.7 & 87.7 & 49 & 69 & 0.0 \\
\hline December & 23.0 & 6.8 & 14.9 & 87 & 51 & 69 & 0.0 \\
\hline January & 20.6 & 4.3 & 12.5 & 92.8 & 49 & 72 & 0.2 \\
\hline February & 24.9 & 8.4 & 16.3 & 80.2 & 42 & 66 & 0.0 \\
\hline March & 31.7 & 13.5 & 22.5 & 83 & 44.8 & 57.4 & 0.0 \\
\hline
\end{tabular}


Table.3 Influence of fertilizer and its application depth on germination count

\begin{tabular}{|l|c|c|}
\hline \multicolumn{1}{|c|}{ Treatments } & \multicolumn{2}{|c|}{ Germination count/m } \\
\hline & (11 DAS) & $(\mathbf{1 8} \mathbf{D A S})$ \\
\hline T1 $\left(\mathbf{B}_{\mathbf{5 0} \%} \mathbf{D}_{\mathbf{7}}\right)$ & $16^{\mathrm{A}}$ & $75^{\mathrm{C}}$ \\
\hline T2 $\left(\mathbf{B}_{\mathbf{8 0} \%} \mathbf{D}_{\mathbf{7}}\right)$ & $11^{\mathrm{A}}$ & $62^{\mathrm{D}}$ \\
\hline T3 $\left(\mathbf{B}_{\mathbf{5 0} \%} \mathbf{D}_{\mathbf{9}}\right)$ & $16^{\mathrm{A}}$ & $82^{\mathrm{AB}}$ \\
\hline T4 $\left(\mathbf{B}_{\mathbf{8 0} \%} \mathbf{D}_{\mathbf{9}}\right)$ & $14^{\mathrm{A}}$ & $88^{\mathrm{A}}$ \\
\hline T5 (Urea) & $15^{\mathrm{A}}$ & $81^{\mathrm{BC}}$ \\
\hline
\end{tabular}

Means followed by the same letter or letters do not differ significantly at $\mathrm{P} \leq 0.05$

Table.4 Influence of UAN basal dose and application depth on plant height

\begin{tabular}{|c|c|c|c|}
\hline Treatments & \multicolumn{3}{|c|}{ Plant Height (cm) } \\
\hline & 45DAS & 72 DAS & 120 DAS \\
\hline $\mathbf{T} 1\left(\mathbf{B}_{50 \%} \mathbf{D}_{7}\right)$ & $36^{\mathrm{B}}$ & $62^{\mathrm{BC}}$ & $86^{\mathrm{A}}$ \\
\hline T2 $\left(\mathbf{B}_{80 \%} \mathbf{D}_{7}\right)$ & $34^{\mathrm{B}}$ & $62^{\mathrm{BC}}$ & $87^{\mathrm{A}}$ \\
\hline T3 (B $\left.\mathbf{B}_{50 \%} \mathbf{D}_{9}\right)$ & $42^{\mathrm{A}}$ & $68^{\mathrm{A}}$ & $89^{\mathrm{A}}$ \\
\hline T4 (B $\left.\mathbf{B}_{80 \%} \mathrm{D}_{9}\right)$ & $41^{\mathrm{A}}$ & $66^{\mathrm{AB}}$ & $89^{\mathrm{A}}$ \\
\hline T5 (Urea) & $35^{\mathrm{B}}$ & $59^{\mathrm{C}}$ & $86^{\mathrm{A}}$ \\
\hline
\end{tabular}

Means followed by the same letter or letters do not differ significantly at $\mathrm{P} \leq 0.05$

Table.5 Influence of UAN basal and application depth on no. of tillers

\begin{tabular}{|l|c|c|c|}
\hline Treatments & \multicolumn{3}{|c|}{ No. of tillers/m } \\
\hline T1 $\left(\mathbf{B}_{\mathbf{5 0} \%} \mathbf{D}_{\mathbf{7}}\right)$ & $45 \mathrm{DAS}$ & $72 \mathrm{DAS}$ & 120 DAS \\
\hline T2 $\left(\mathbf{B}_{\mathbf{8 0} \%} \mathbf{D}_{\mathbf{7}}\right)$ & $157^{\mathrm{A}}$ & $180^{\mathrm{B}}$ & $165^{\mathrm{A}}$ \\
\hline T3 $\left(\mathbf{B}_{\mathbf{5 0} \%} \mathbf{D}_{\mathbf{9}}\right)$ & $140^{\mathrm{B}}$ & $161^{\mathrm{D}}$ & $144^{\mathrm{B}}$ \\
\hline T4 $\left(\mathbf{B}_{\mathbf{8 0} \%} \mathbf{D}_{\mathbf{9}}\right)$ & $157^{\mathrm{A}}$ & $188^{\mathrm{A}}$ & $173^{\mathrm{A}}$ \\
\hline T5 (Urea) & $159^{\mathrm{A}}$ & $191^{\mathrm{A}}$ & $167^{\mathrm{A}}$ \\
\hline
\end{tabular}

Table.6 Influence of UAN basal dose and application depth on biological and grain yield

\begin{tabular}{|l|c|c|}
\hline Treatments & $\begin{array}{c}\text { Biological yield } \\
\left(\mathbf{g} / \mathbf{m}^{\mathbf{2}}\right)\end{array}$ & $\begin{array}{c}\text { Grain yield } \\
\left(\mathbf{g} / \mathbf{m}^{\mathbf{2}}\right)\end{array}$ \\
\hline T1 $\left(\mathbf{B}_{\mathbf{5 0} \%} \mathbf{D}_{\mathbf{7}}\right)$ & $1567^{\mathrm{A}}$ & $650^{\mathrm{B}}$ \\
\hline T2 $\left(\mathbf{B}_{\mathbf{8 0} \%} \mathbf{D}_{\mathbf{7}}\right)$ & $1306^{\mathrm{B}}$ & $522^{\mathrm{C}}$ \\
\hline T3 $\left(\mathbf{B}_{\mathbf{5 0} \%} \mathbf{D}_{\mathbf{9}}\right)$ & $1321^{\mathrm{B}}$ & $555^{\mathrm{C}}$ \\
\hline T4 $\left(\mathbf{B}_{\mathbf{8 0} \%} \mathbf{D}_{\mathbf{9}}\right)$ & $1686^{\mathrm{A}}$ & $736^{\mathrm{A}}$ \\
\hline T5 (Urea) & $1628^{\mathrm{A}}$ & $687^{\mathrm{B}}$ \\
\hline
\end{tabular}

Means followed by the same letter or letters do not differ significantly at $\mathrm{P} \leq 0.05$ 
Fig.1 Simultaneous placement of wheat seed and UAN fertilizer by UAN applicator

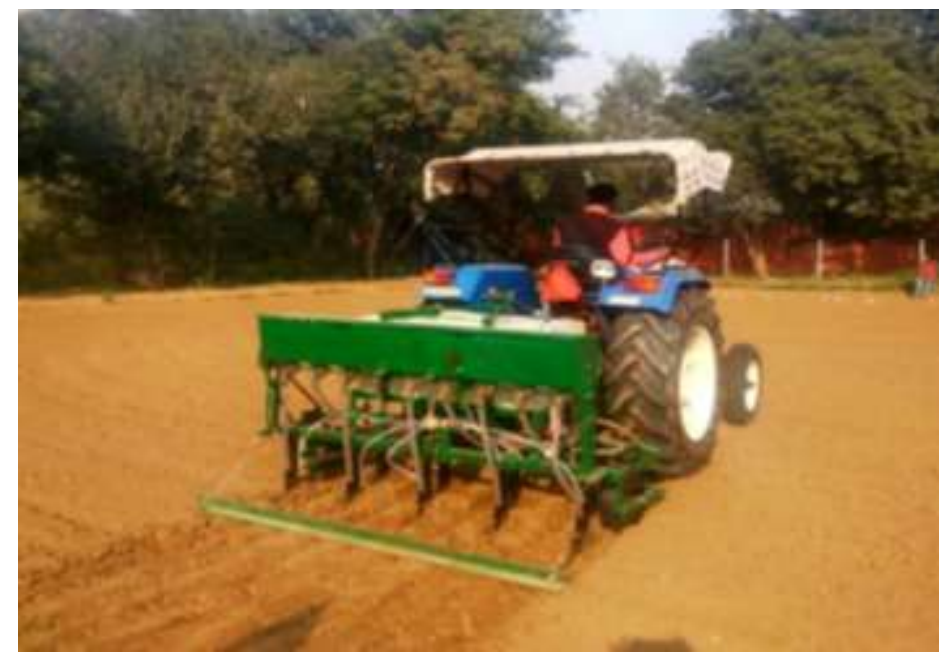

Fig.2 Mean monthly temperature and RH in selected months of the year 2017 -18

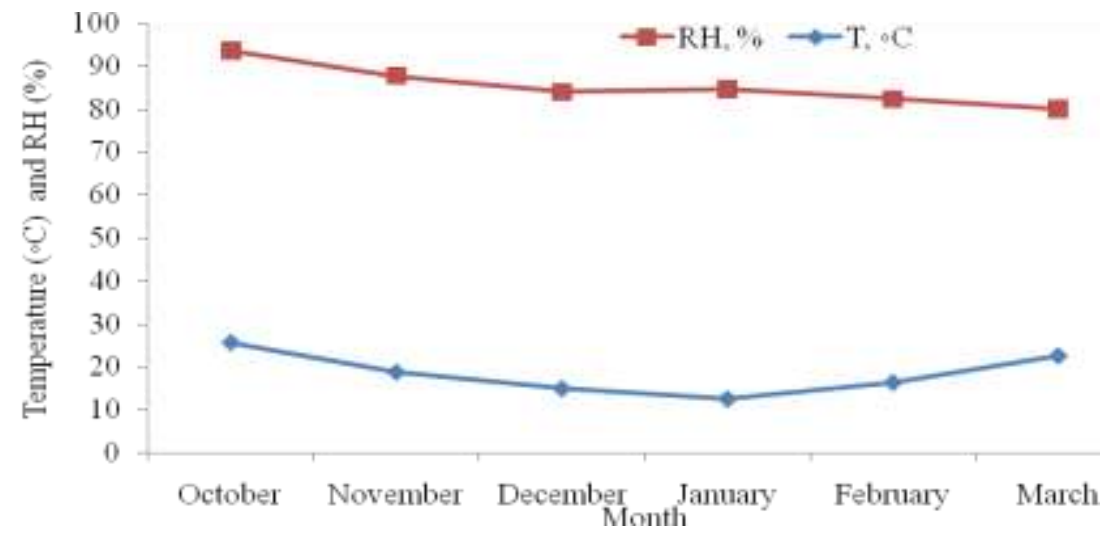

The expected relative yield of the crop under different treatments was evaluated by measuring the grain yield per unit area $\left(\mathrm{g} / \mathrm{m}^{2}\right)$ of the crop area. The highest grain yield of 736 $\mathrm{g} / \mathrm{m}^{2}$ was observed in the treatment in which $50 \%$ basal dose of $\mathrm{N}$ in the form of UAN was applied at a depth of $9 \mathrm{~cm}$ from soil surface. This was because of the more number of spikelets obtained in this treatment. Biological yield is an important factor because farmers are also interested in straw in addition to grain. The biological yield observed in treatment $\mathrm{T} 1, \mathrm{~T} 4$ and T5 was significantly higher as compared than T2 and T3 at $5 \%$ level of significance. The highest and lowest biological yield of $1680 \mathrm{~g} / \mathrm{m}^{2}$ and $1320 \mathrm{~g} / \mathrm{m}^{2}$ was observed in treatments observed when $80 \%$ basal dose of $\mathrm{N}$ was applied at $9 \mathrm{~cm}$ and $7 \mathrm{~cm}$, respectively. The higher biological yield observed in $80 \% \mathrm{~N}$ as basal dose compared to $50 \% \mathrm{~N}$ may be due to effect of Nitrogen on vegetative growth of wheat. Shah et al., (2011) and Geleto et al., (1995) also reported higher biological yield in increased Nitrogen dosage.

Based upon the crop response results of wheat crop to UAN, it is imperative that UAN placed at proper depth from seed leads to better germination and higher crop yield compared to that of Urea application. It was inferred that to get a good germination count, UAN in appropriate amount needs to be placed at an 
optimum depth from seed to avoid toxicity affect and loss of seed injury. The application of $80 \%$ basal dose of Nitrogen through UAN (@ $120 \mathrm{kgN} / \mathrm{ha}$ ) resulted into either at par or significantly higher crop growth and crop yield than that of Urea application (@150 kgN/ha). Thus, for same yield, a minimum fertilizer saving of $30 \mathrm{kgN} / \mathrm{ha}$ could be attained with UAN application in place of Urea application.

\section{Acknowledgement}

Authors acknowledge theNational Fertilizer Limited, Noida, India and Department of Fertilizer, (Government of India) for providing financial support in the form of contract research project.

\section{References}

Anonymous, 2012, Value Added fertilizers and site specific nutrient management. Policy Paper 57.National Academy of Agricultural Sciences, New Delhi.

Anonymous, 2016, Indian Fertilizer Scenario2015. Department of Fertilizers. Ministry of Chemicals and Fertilizers. Government of India. pp304.

Cooke, I.J., 1962, Toxic effects of urea on plants. Nature, 149:1262-1263.

Gagnon, B. and Ziadi, N., 2010, Grain corn and soil nitrogen responses to sidedress nitrogen sources and application. Agronomy Journal 103(3):1014-22.

Geleto, T., Tanner, D.G., Mamo, T., and Gebeyehu, G., 1995, Response of rainfed bread and durum wheat to source, level and timings of nitrogen fertilization on two Ethiopian vertisols.Comm. Soil Sci. \& Plant Analys., 26(11):17773-17794.
Hadjichristodoulou, A., Della, A. and Photiades, J., 1977, Effect of sowing depth on plant establishment, tillering capacity and other agronomic characters of cereals. The Journal of Agricultural Science89(1): 161-7.

IPNI., 2017. http://www.ipni.net/specifics-en Nutrient Source Specifics accessed on 05 Jan 2017.

Pan, W. L., Madsen, I.J., Bolton, R.P., Graves, L. and Sistrunk, T., 2016, Ammonia/ammonium toxicity root symptoms induced by inorganic and organic fertilizers and placement. Agron. J., 108:2485-2492.

Radford, B. J., Strong, W. M. and Wildermuth, G. B, 1989, Effects of urea and flutriafol on germination, coleoptile length and establishment of wheat and barley. Australian J. of Experimental Agriculture, 29: 551-557.

Shah, W.A., Khan, H.U., Anwar S., and Nawab, K., 2011, Yield and yield components of wheat as affected by different seed rates and nitrogen levels. Sarhad $J$. Agric., 27:27-25.

Sundaram, P. K., Mani I., Kumar, A., Lande S.D., Sarkar, S.K., Manjaiya, K.M., Sahoo, R.N. and Lal, S.K., 2017, Effect of liquid urea ammonium nitrate application at varying depths on root and shoot growth in wheat (Triticum aestivum). Indian Journal of Agricultural Sciences 87 (10): 12881294.

Wu, M., Li, G., Li, W., Liu, J., Liu, M., Jiang, C., and Li, Z., 2017, Nitrogen fertilizer deep placement for increased grain yield and nitrogen recovery efficiency in rice grown in Subtropical China. Front Plant Sci., 8: 1227.

\section{How to cite this article:}

Prem K. Sundaram, Indra Mani, Satish D. Lande and Roaf Ahmad Parray. 2019. Evaluation of Urea Ammonium Nitrate Application on the Performance of Wheat. Int.J.Curr.Microbiol.App.Sci. 8(01): 1956-1963. doi: https://doi.org/10.20546/ijcmas.2019.801.205 